\title{
Radioactivity of some building and raw materials used in Croatia
}

\author{
Tahir Sofilićc ${ }^{*}$, Delko Barišić ${ }^{2}$, Una Sofilićc ${ }^{3}$, Marija Đurokovićc \\ ${ }^{1}$ CMC Sisak d.o.o., Braće Kavurić 12, 44010 Sisak, Croatia \\ ${ }^{2}$ Rudjer Bošković Institute, Bijenička cesta 54, 10000 Zagreb, Croatia \\ ${ }^{3}$ Jaruščica 9E, 10000 Zagreb, Croatia \\ ${ }^{4}$ Nexe Grupa d.d., Braće Radića 200, 31500 Našice, Croatia \\ * Corresponding author: e-mail: tahir.sofilic@cmc.com
}

In the present study, the activity concentrations of ${ }^{226} \mathrm{Ra},{ }^{232} \mathrm{Th},{ }^{40} \mathrm{~K}$ in some building and raw materials used in Croatia were measured by using a gamma-ray spectrometer with the HPGe detector. The average activity concentrations of the studied different building and raw materials ranged from $11.6 \pm 1.7$ (concrete) to 251.2 $\pm 25.7 \mathrm{Bqkg}^{-1}$ (GBFS), $14.0 \pm 2.7$ (concrete) to $54.4 \pm 8.3$ (coal fly ash) and $147.2 \pm 19.0$ (concrete) to $773.7 \pm 82.0 \mathrm{Bqkg}^{-1}$ (tuff) for ${ }^{226} \mathrm{Ra},{ }^{232} \mathrm{Th}$ and ${ }^{40} \mathrm{~K}$, respectively. Radium equivalent activity, activity concentration index, absorbed gamma dose rate indoor due to the external exposure and corresponding annual effective dose were determined to estimate the exposure risk arising due to the use of these building and raw materials.

Keywords: Radioactivity; Building materials; Fly ash; Gamma-ray spectrometer; Annual effective dose.

\section{INTRODUCTION}

High consumption of raw materials from natural sources, high amount generating of industrial by-products and environmental impact require finding new solutions for a sustainable development. Materials generated as by-products from industrial processes can be used in various ways in the building industry. Recent studies showed that applications of nontraditional materials (industrial by-products), have been considered in building industry ${ }^{1-19}$. In last three decade there is a growing tendency to use of industrial byproducts in the world. Especially cement and concrete industry uses large amounts of industrial by-products.

The industrial by-products such as coal fly ash are in many features similar to building materials like cement. With this, it is of vital importance to be familiar with the technical significance of the secondary application of industrial by-products, but also with their possible environmental effects, because some of them might contain increased concentrations of substances harmful to human health or the environment.

Many non-nuclear industries generate by-products in which the concentration of naturally occurring radioactive material is additionally enhanced. Usually the amount of such type of by-products can be up to hundreds of thousands of tones. At the same time the by-products containing enhanced activities of naturally radionuclides can be used as secondary raw material in another industry, causing a significant impact on the environment. The problem of natural radioactivity is completely excluded from regulations dealing with the environmental protection in general and the hazard caused by radiation, originating from naturally radioactive materials is rarely taken into consideration when the treatment or utilization of industrial byproducts and/or waste is planned.

All building materials derived from rock and soil contain naturally occurring radioactive material (NORM), mainly natural radionuclides of the uranium $\left({ }^{238} \mathrm{U}\right)$ and thorium $\left.{ }^{232} \mathrm{Th}\right)$ series, and the radioactive isotope of potassium $\left({ }^{40} \mathrm{~K}\right)$. In the uranium series, the decay chain segment starting from radium ${ }^{226} \mathrm{Ra}$ is radiological the most important and, therefore, reference is often made to radium instead of uranium. In natural raw materials for cement, concrete, bricks, mortar and other building material the activity concentrations of ${ }^{238} \mathrm{U},{ }^{226} \mathrm{Ra},{ }^{232} \mathrm{Th}$ and ${ }^{40} \mathrm{~K}$ varies considerably, depending on both the nature and the origin of the compounds. Generally, natural building materials reflect the geology of their site of origin and the average activity concentrations of ${ }^{226} \mathrm{Ra},{ }^{232} \mathrm{Th}$ and ${ }^{40} \mathrm{~K}$ in the Earth's crust are about 40, 40 and $400 \mathrm{Bqkg}^{-1}$ respectively ${ }^{11}$.

Nowadays, due to a relatively high share of industrial byproducts as raw material in the total amount of building material produced throughout the world, activity concentrations of radionuclides is becoming increasingly important. This industrial by-product can represent a polluting radioactive source by its using as addition in building materials. This determines a supplementary radiation hazard towards the natural radioactivity background, which cannot be neglected. Because the industrial by-products which are incorporated into the building materials can contain radionuclides, there is a reason to suspect that the so obtained building material can contain enhanced levels of natural radionuclides, The activity concentrations of these nuclides in the final product should be measured or assessed reliably from the activities of all component materials.

In this manner, the presence of natural radionuclides was determined in the samples of natural raw material used in the building material making process, as well as the produced building materials. This paper considers the radiation risk assessment of population based on these radionuclides if the coal fly ashes from thermal power station and granulated blast furnace slag as addition at cements and concretes fabrication are used, the measurements being made on ash/slag-cement-concrete chain. Therefore the activity concentrations of ${ }^{226} \mathrm{Ra},{ }^{232} \mathrm{Th}$ and ${ }^{40} \mathrm{~K}$ in the used industrial by-products have been measured using the gamma-ray spectrometric technique and compared with the values of same radionuclide in some type of the products (Portland cement, mixed Portland cement, masonry cement and concrete) obtained by the use of these artificial building material components in the Nexe Grupa, Našice, Croatia. 


\section{EXSPERIMENTAL PART}

The measurement has been conducted on the used byproducts and obtained different kinds of cement, concrete and mortar created during the production in the Nexe Grupa, Našice. To evaluate the radiological risk due to building materials, the activity concentrations of reference radionuclides: ${ }^{226} \mathrm{Ra},{ }^{232} \mathrm{Th}$ and ${ }^{40} \mathrm{~K}$, in coal fly ash samples from thermal power station, granulated blast furnace slag (GBFS), natural puzzolana (tuff) and building materials (Portland cement, mixed Portland cement, masonry cement and concrete) obtained by addition mentioned byproducts was measured by g-ray spectrometry. A broad type of a detector with the following characteristics was used: active diameter $70 \mathrm{~mm}$, active area $3800 \mathrm{~mm}^{2}$, thickness 30 $\mathrm{mm}$, window thickness $0,5 \mathrm{~mm}$, window material - carbon epoxy, bias voltage $4500 \mathrm{~V}$, energy resolution (FWHM) at $59,5 \mathrm{keV}$ of $554 \mathrm{eV}$ (FWTM $1032 \mathrm{eV}$ ) FWHM at 1332,5 $\mathrm{keV}$ of $2053 \mathrm{eV}$ (FWTM 4106).

\section{Sampling}

The by-product samples were crushed in a ring mill to the grain size below $1 \mathrm{~mm}$, homogenized, and quartered to the quantity of $1 \mathrm{~kg}$. The samples in the powder form were dried at $378 \mathrm{~K}$ in a temperature-controlled furnace until there was no delectable change in the mass of the sample, transferred to glass bottles with a ground cap, and marked. The samples were dried, homogenized, placed into standard counting vessels of $125 \mathrm{~cm}^{3}$ and weighed. The loaded vessels were sealed and stored for at least 4 weeks to allow the in-growth of gaseous ${ }^{222} \mathrm{Rn}$ (3.8 day half-life) and its short-lived decay products to equilibrate with the longlived ${ }^{226} \mathrm{Ra}$ precursor in the sample. At the end of the ingrowth period, the samples were counted.

\section{Quantitative determination}

The activity concentrations of ${ }^{226} \mathrm{Ra},{ }^{232} \mathrm{Th}$ and ${ }^{40} \mathrm{~K}$ in the examined samples were determined by gamma-ray spectrometry, using a low background hyper pure germanium semiconductor detector system coupled to 8192-channel CANBERRA analyzer. The detector system was calibrated using the gamma mixed standards supplied by Eckert \& Ziegler (Analytics USA).

Depending on the sample mass and activity, the spectra were recorded for times ranging 80,000-200,000 seconds, and analyzed using the GENIE 2K CANBERRA software. Activities of ${ }^{226} \mathrm{Ra}$ were calculated from the $609.4 \mathrm{keV}$ - peak of its ${ }^{214} \mathrm{Bi}$ progeny. Activities of ${ }^{232} \mathrm{Th}$ were calculated over ${ }^{228} \mathrm{Ra}$ from the $911.1 \mathrm{keV}$-peak of its ${ }^{228} \mathrm{Ac}$ progeny. Activities of ${ }^{40} \mathrm{~K}$ were calculated from the 1460.7 keV-peak.

The efficiency of the system was regularly checked during the inter-comparison runs. The precision and accuracy of the system were checked additionally by a simultaneous measurement of IAEA Reference Materials (International Atomic Energy Agency) as Laboratory is accredited by Croatian Accreditation Agency for gammaspectrometric measurements (HRN EN ISO/IEC 17025:2007). It should be mentioned that the efficiency was calculated as the function of energy and geometry on the base of experimental data. The measured uncertainty, multiplied by coverage factor $\mathrm{k}=2$, was calculated as the sum of net peak area uncertainty, efficiency uncertainty and background fluctuation uncertainty.

\section{RESULTS AND DISCUSSION}

The obtained results of the activity concentrations of ${ }^{226} \mathrm{Ra},{ }^{232} \mathrm{Th}$ and ${ }^{40} \mathrm{~K}$ in examined Croatian building and raw materials are presented in Table 1.

The measured values regarding the presence of individual isotopes and their activity were as follows: ${ }^{40} \mathrm{~K}$ from $147.2 \pm 19.0 \mathrm{Bqkg}^{-1}$ (concrete) to $773.7 \pm 82.0 \mathrm{Bqkg}^{-1}$ (tuff); ${ }^{232} \mathrm{Th}$ from $14.0 \pm 2.70 \mathrm{Bqkg}^{-1}$ (concrete) to $54.4 \pm 8.33 \mathrm{Bqkg}^{-1}$ (coal fly ash) and ${ }^{226} \mathrm{Ra}$ from $11.6 \pm 1.70 \mathrm{Bqkg}^{-1}$ (concrete) to $251.2 \pm 25.7 \mathrm{Bqkg}^{-1}$ (GBFS).

Generally, building materials can contain ${ }^{226} \mathrm{Ra},{ }^{232} \mathrm{Th}$ and ${ }^{40} \mathrm{~K}$ due to their natural occurrence in the raw materials, or if a recycled industrial product, for example steel slag in concrete, or the industrial by-product, such as coal fly ash and slag, has the elevated levels of NORM. Generally, the radionuclide concentration in the final material will be lower than that of the original by-product because of the presence of other inert material in the particular building material. There have been a number of investigations of the radionuclide content in building materials ${ }^{23-26}$, and levels generally fall in the published ranges for various materials.

Most of the countries use unit $\mathrm{Bqkg}^{-1}$ for activity concentrations but at the same time some of the other countries ${ }^{19}$, which have similar regulations, apply $\mathrm{Bqm}^{-3}$ as the unit.

Table 1. The activity concentrations of ${ }^{226} \mathrm{Ra},{ }^{232} \mathrm{Th}$ and ${ }^{40} \mathrm{~K}$ measured in the samples examined and the radium equivalent concentrations $\left(\mathrm{Ra}_{\mathrm{eq}}\right)$ calculated for the samples

\begin{tabular}{|l|c|c|c|c|}
\hline \multicolumn{1}{|c|}{ Material } & \multicolumn{2}{c|}{ Activity concentration $\left(\mathrm{Bq} \mathrm{kg}^{-1}\right)$} & \multicolumn{2}{c|}{${ }^{40} \mathrm{~K}$} \\
\hline $\begin{array}{l}\text { Most common building materials } \\
\text { (may include by-products) }\end{array}$ & ${ }^{226} \mathrm{Ra}$ & ${ }^{232} \mathrm{Th}$ & ${ }^{2}$ & \\
\hline Sand & $11.3 \pm 1.7$ & $17.6 \pm 2.9$ & $225.4 \pm 26.0$ & 53.8 \\
\hline Tuff & $36.9 \pm 4.4$ & $26.6 \pm 4.3$ & $773.7 \pm 82.0$ & 134.5 \\
\hline CEM I 52.5 N - Portland cement & $129.6 \pm 13.7$ & $23.3 \pm 4.8$ & $255.4 \pm 31.8$ & 182.6 \\
\hline CEM II/B-M (P-S) 32, 5R - mixed Portland cement & $129.0 \pm 13.5$ & $23.1 \pm 4.5$ & $307.3 \pm 36.5$ & 185.7 \\
\hline CEM II/A-M (S-V) 42,5N - mixed Portland cement & $131.6 \pm 13.9$ & $25.4 \pm 4.8$ & $252.4 \pm 36.0$ & 187.4 \\
\hline Masonry cement & $128.0 \pm 13.6$ & $15.3 \pm 4.0$ & $156.1 \pm 22.6$ & 161.9 \\
\hline Concrete & $11.6 \pm 1.7$ & $14.0 \pm 2.7$ & $147.2 \pm 19.0$ & 43.0 \\
\hline $\begin{array}{l}\text { Most common industrial by products used in building } \\
\text { materials }\end{array}$ & & & & \\
\hline Coal fly ash & $53.3 \pm 6.4$ & $54.4 \pm 8.3$ & $361.7 \pm 44.8$ & 158.9 \\
\hline Granulated blast furnace slag (GBFS) & $251.2 \pm 25.7$ & $24.8 \pm 5.0$ & $214.2 \pm 28.0$ & 303.2 \\
\hline
\end{tabular}


In Croatia, to limit the increase of natural background of radiation indoors, caused by the use of materials with high radioactivity in building, the Ministry of Health and Social Welfare introduced in 2008 the norms for the contents of natural radioactive elements in raw and building materi$\mathrm{als}^{20}$. Article 34 of the cited Croatian Ordinance defines the so called activity index $\left(\mathrm{Bqkg}^{-1}\right)$ for qualifying whether building raw materials and final materials are acceptable for building houses designed for habitation. For the building material to be used as supplement in the production of building materials it is essential to fulfill the prescribed values of maximum limit radioactive pollution of construction material, which should not exceed the following concentration of activities:

$300 \mathrm{Bqkg}^{-1}$ for ${ }^{226} \mathrm{Ra}$

$200 \mathrm{Bqkg}^{-1}$ for ${ }^{232} \mathrm{Th}$

$3000 \mathrm{Bqkg}^{-1}$ for ${ }^{40} \mathrm{~K}$

So that this condition is met:

$\left(C_{R a} / 300\right)+\left(C_{T h} / 200\right)+\left(C_{K} / 3000\right) \leq 1$

Where $\mathrm{C}_{\mathrm{Ra}}, \mathrm{C}_{\mathrm{Th}}$ and $\mathrm{C}_{\mathrm{K}}$ are the activity concentrations of ${ }^{226} \mathrm{Ra},{ }^{232} \mathrm{Th}$ and ${ }^{40} \mathrm{~K}$, respectively $\left(\mathrm{Bqkg}^{-1}\right)$.

The calculated activity concentration index values of present radionuclides in the analyzed samples are as follows: $0.20 \mathrm{Bqkg}^{-1}$ (sand), $0.51 \mathrm{Bqkg}^{-1}$ (tuff), $0.63 \mathrm{Bqkg}^{-1}$ (CEM I $52.5 \mathrm{~N}$ - Portland cement), $0.65 \mathrm{Bqkg}^{-1}$ (CEM II/ A-M (S-V) 42,5N - mixed Portland cement), $0.56 \mathrm{Bqkg}^{-1}$ (masonry cement), $0.16 \mathrm{Bqkg}^{-1}$ (concrete), $0.57 \mathrm{Bqkg}^{-1}$ (coal fly ash) and $1.00 \mathrm{Bqkg}^{-1}$ (granulated blast furnace slag).

Available literature data ${ }^{20}$ shows typical and maximum activity concentrations in common building materials and industrial by-products used for building materials in EU. The radioactivity concentrations found in some kind of industrial by-products (fly ash, phosphogypsum, etc.) can often be significantly higher in comparison with the most common building materials.

The recently published European Commission document ${ }^{11}$ provides the guidance for setting controls on the radioactivity of building materials in European countries. This document is the first comprehensive act which sets the principles of radiological protection principles concerning the natural radioactivity of building materials and it is relevant for the newly produced building materials and not intended to be applied to existing buildings.
Most of the European countries apply their controls based on the upper end of the dose scale $\left(1.0 \mathrm{mSvy}^{-1}\right)$, however some of them apply the strictest criterion based on the lower end of the dose scale $\left(0.3 \mathrm{mSva}^{-1}\right)$. At the same time many of the European and other countries, which have similar regulations, apply more liberal dose criteria. European and non-European countries with reference levels for radionuclides in building materials apply activity index or maximum allowed/recommended concentrations (Table 2). The activity concentration index is calculated on the basis of the activity concentrations of ${ }^{226} \mathrm{Ra},{ }^{232} \mathrm{Th}$ and ${ }^{40} \mathrm{~K}$. Artificial radionuclides are sometimes taken into consideration $^{21,22}$ as well (Lithuania, Finland and Slovenia).

In order to compare the specific activities of materials containing different amounts of ${ }^{226} \mathrm{Ra},{ }^{232} \mathrm{Th}$ and ${ }^{40} \mathrm{~K}$, numerous authors ${ }^{24-26}$ have applied an index, called the radium equivalent concentration $\left(\mathrm{Ra}_{\mathrm{eq}}\right)$ defined based on the previous investigations, that $370 \mathrm{Bqkg}^{-1}$ of ${ }^{226} \mathrm{Ra}, 259$ $\mathrm{Bqkg}^{-1}$ of ${ }^{232} \mathrm{Th}$ and $4810 \mathrm{Bqkg}^{-1}$ of ${ }^{40} \mathrm{~K}_{\text {produce the same }}$ gamma dose rate. Therefore, the $\mathrm{Ra}_{\mathrm{eq}}$ of building material can be written as:

$\mathrm{Ra}_{\mathrm{eq}}=C_{R a}+1.43 C_{T h}+0.077 C_{K}$

where $C_{R a}, C_{T h}$ and $C_{K}$ are the activity concentrations of ${ }^{226} \mathrm{Ra},{ }^{232} \mathrm{Th}$ and ${ }^{40} \mathrm{~K}$, respectively, $\mathrm{Bqkg}^{-1}$.

From the obtained activity concentrations values of ${ }^{226} \mathrm{Ra}$, ${ }^{232} \mathrm{Th}$ and ${ }^{40} \mathrm{~K}$ of investigated samples, the radium equivalent concentrations were computed and the results are presented in Table 1.

The calculated values of radium equivalent $\left(\mathrm{Ra}_{\mathrm{eq}}\right)$ ranges from $43.0 \mathrm{Bqkg}^{-1}$ in concrete sample to $303.2 \mathrm{Bqkg}^{-1}$ in GBFS sample. The so obtained values of radium equivalent concentrations in investigated by-product samples, as well as in some final building products were compared with the results of radium equivalent in the same materials published before, Table 3 .

The obtained results were consistent with the results of radium equivalent concentrations in the same materials from earlier study carried out by other authors ${ }^{48}$.

According to Radiological Protection Principles ${ }^{11}$ when industrial by-products are incorporated in building materials and there is a reason to suspect that these contain enhanced levels of natural radionuclides, the activity concentrations of these nuclides in the final product should be

Table 2. Activity index and maximum allowed or recommended concentrations in building materials in some European countries $^{21,22}$

\begin{tabular}{|l|c|}
\hline Country & Activity Indeks $\left(\mathrm{Bqkg}^{-1}\right)$ \\
\hline Austria & $\left(C_{R a} / 300\right) \times(1+0.15 \times$ density $\mathrm{x}$ thickness $)+\left(C_{T h} / 600\right)+\left(C_{K} / 10000\right)<1$ \\
\hline Finland & $\left(C_{R a} / 300\right)+\left(C_{T h} / 200\right)+\left(C_{K} / 3000\right)<1$ \\
Residential building & $\left(C_{R a} / 700\right)+\left(C_{T h} / 500\right)+\left(C_{K} / 8000\right)+\left(C_{C s} / 2000\right)<1$ \\
Roads, streets /populated areas & $\left(C_{R a} / 2000\right)+\left(C_{T h} / 1500\right)+\left(C_{K} / 20000\right)+\left(C_{C s} / 5000\right)<1$ \\
Landfilling/Landscaping & $\left(C_{R a} / 4000\right)+\left(C_{T h} / 3000\right)+\left(C_{K} / 50000\right)+\left(C_{C s} / 10000\right)<1$ \\
Handling of ash & $\left(C_{R a}+C_{T h}\right) / 170<1 ; C_{K}<1500 \mathrm{Bqkg}^{-1}$ \\
\hline Latvia & $\left(C_{R a}+C_{T h} / 250<1 ; C_{K}<2000 \mathrm{Bqkg}^{-1}\right.$ \\
Residential building & $\left(C_{R a}+C_{T h}\right) / 300<1 ; C_{K}<2500 \mathrm{Bqkg}^{-1}$ \\
Industrial building & $\left(C_{R a} / 300\right)+\left(C_{T h} / 200\right)+\left(C_{K} / 3000\right)<1$ \\
Roads/populated areas & $\left(C_{R a} / 700\right)+\left(C_{T h} / 500\right)+\left(C_{K} / 8000\right)+\left(C_{C s} / 2000\right)<1$ \\
\hline Lithuania & $\left(C_{R a} / 2000\right)+\left(C_{T h} / 1500\right)+\left(C_{K} / 20000\right)+\left(C_{C s} / 5000\right)<1$ \\
All building material & $\left(C_{R a} / 300\right)+\left(C_{T h} / 200\right)+\left(C_{K} / 3000\right)<1 ; C_{R a}<200 \mathrm{Bqkg}^{-1}$ \\
Streets, roads, etc. & $0.0027 C_{R a}+0.0043 C_{T h}+0.00027 C_{K}<1 ; C_{R a}<185 \mathrm{Bqkg}{ }^{-1}$ \\
Landscaping & $\left(C_{R a} / 400\right)+\left(C_{T h} / 300\right)+\left(C_{K} / 5000\right)+\left(C_{a r t i f} / 5000\right)<1$ \\
\hline Norway & \\
\hline Poland & \\
\hline Slovenia &
\end{tabular}


Table 3. Comparison of $\mathrm{Ra}_{\mathrm{eq}}\left(\mathrm{Bqkg}^{-1}\right)$ in the investigated samples to the results of similar studies reported in different countries ${ }^{24}$

\begin{tabular}{|l|c|c|c|r|}
\hline \multirow{2}{*}{ Country } & \multicolumn{4}{|c|}{$\mathrm{Ra}_{\mathrm{eq}}\left(\mathrm{Bqkg}^{-1}\right)$} \\
\cline { 2 - 5 } & Sand & $\begin{array}{c}\text { Portland } \\
\text { cement }\end{array}$ & Fly ash & \multicolumn{1}{l|}{ Slag } \\
\hline This study & 53.8 & 182.6 & 158.9 & 303.2 \\
\hline Germany & 59.2 & 70.3 & 451.4 & 421.8 \\
\hline Norway & NA & 7.4 & NA & 27.4 \\
\hline Sweden & NA & 140.6 & NA & 351.5 \\
\hline United Kingdom & 18.5 & 59.2 & NA & 170.2 \\
\hline Australia & 70.3 & 114.7 & 355.2 & 340.4 \\
\hline India & 170.8 & 104.7 & 109.2 & 189.8 \\
\hline
\end{tabular}

measured or assessed reliably from the activities of all component materials. The dose criterion should be applied to the final product. Some traditionally used natural building materials contain natural radionuclides at levels such that the annual dose of $1 \mathrm{mSv}$ might be exceeded.

According to Radiological Protection Principles ${ }^{11}$ the absorbed dose rate in air in a room can be calculated by using the specific dose rates $\left(D, \mathrm{nGyh}^{-1}\right.$ per $\left.\mathrm{Bqkg}^{-1}\right)$ for ${ }^{226} \mathrm{Ra},{ }^{232} \mathrm{Th}$ and ${ }^{40} \mathrm{~K}$ are given for different materials.

Dose rate indoors $(D)$ for concrete are calculated according to the given equations as follows:

$\mathrm{D}=0.92 C_{R a}+1.1 C_{T h}+0.08 C_{K}$

The calculated values of dose rate indoors for the investigated concrete were used to calculate annual effective doses $\left(D_{E}\right)$, due to gamma radiation according to next equation:

$D_{E}=0.7 \mathrm{SvGy}^{-1} \cdot 7000 \mathrm{~h} \cdot D$

where $D$ must be taken in $\mu \mathrm{Gy} \mathrm{h}^{-1}$, effective absorbed dose conversion factor is $0.7 \mathrm{SvGy}^{-1}$ and annual exposure time is $7000 \mathrm{~h}$.

The obtained result for annual effective dose was 0.183 $\mathrm{mSv}$ and do not exceed the limits defined in Radiological Protection Principles ${ }^{11}$.

\section{CONCLUSION}

In this study the natural radionuclide contents, activity concentration index, dose rate and annual effective dose from some building materials were determined.

The measured values regarding the presence of individual isotopes and their activity were as follows: ${ }^{40} \mathrm{~K}$ from $147.2 \pm 19.0 \mathrm{Bqkg}^{-1}$ (concrete) to $773.7 \pm 82.0 \mathrm{Bqkg}^{-1}$ (tuff); ${ }^{232} \mathrm{Th}$ from $14.0 \pm 2.70 \mathrm{Bqkg}^{-1}$ (concrete) to $54.4 \pm 8.33 \mathrm{Bqkg}^{-1}$ (coal fly ash) and ${ }^{226} \mathrm{Ra}$ from $11.6 \pm 1.70 \mathrm{Bqkg}^{-1}$ (concrete) to $251.2 \pm 25.7 \mathrm{Bqkg}^{-1}$ (GBFS).

From the calculated activity concentration index values of present radionuclides in the analyzed samples we reach the conclusion that the analyzed samples can be used as raw material used in building material making process, as well, as produced building materials, because the calculated index values of present radionuclides are significantly lower than the Croatian maximum allowed limit.

The measured activities of naturally occurring radionuclides in the investigated samples of industrial byproducts and raw building materials are significantly lower than the maximum Croatian allowed limit so that the investigated by-products and building materials, in terms of the radionuclides present, may be applied as raw materials and/ or additives in the production of cement, mortar and concrete, as well as various other building materials.

At the same time the obtained values of radio activities were consistent with the values in the recently published European Commission document Radiological Protection Principles Concerning the Natural Radioactivity of Building Materials, Radiation Protection 112, which provides guidance for setting the controls on the radioactivity of building materials in European countries.

From the obtained activity concentrations values of ${ }^{226} \mathrm{Ra}$, ${ }^{232} \mathrm{Th}$ and ${ }^{40} \mathrm{~K}$ of the investigated samples, the radium equivalent concentrations were calculated. The obtained values of radium equivalent $\left(\mathrm{Ra}_{\mathrm{eq}}\right)$ ranges from $43.0 \mathrm{~Bq} \mathrm{~kg}{ }^{-1}$ in concrete sample to $303.2 \mathrm{~Bq} \mathrm{~kg}{ }^{-1}$ in GBFS sample and the so obtained values of radium equivalent concentrations in the investigated by-product samples, as well as in some final building products were compared with the results of radium equivalent in the same materials published before.

Dose rate indoors for the investigated concrete are calculated according to Radiation Protection 112 and the so obtained values were used to calculate annual effective doses DE. The obtained result for the annual effective dose was $0.183 \mathrm{mSv}$ and do not exceed the limits defined in the above mentioned document.

\section{LITERATURE CITED}

1. Okuno, N., Ishikawa, Y., Shimizu, A. \& Yoshida, M. (2004). Utilization of sludge in building material. Water Sci. Technol. 49 (10), 225-232.

2. Almeida, N., Branco, F. \& Santos, J.R. (2007). Recycling of stone slurry in industrial activities: Application to concrete mixtures. Build. Environ. 42 (2), 810-819. DOI: 10.1016/ j.buildenv.2005.09.018.

3. Chateau, L. (2007). Environmental acceptability of beneficial use of waste as construction material-State of knowledge, current practices and future developments in Europe and in France. J.Hazard.Mater. 139 (3), 556-562. DOI:10.1016/ j.jhazmat.2006.02.064.

4. Badur, S. \& Chaudhary, R. (2008). Utilization of hazardous wastes and by-products as a green concrete material through S/S process: A review. Rev. Adv. Mater. Sci. 17(1-2), 42-61.

5. Singh, M. \& Garg, M. (2008). Utilization of waste lime sludge as building materials. J. Sci. Ind. Res. 67 (2), 161-166.

6. Ducman, V. \& Mirtič, B. (2009). The applicability of different waste materials for the production of lightweight aggregates. Waste Manage 29 (8), 2361-2368. DOI: 10.1016/ j.wasman.2009.02.013.

7. Jaillon, L., Poon, C.S. \& Chiang, Y.H. (2009). Quantifying the waste reduction potential of using prefabrication in building construction in Hong Kong. Waste Manage 29 (1), 309-320. DOI:10.1016/j.wasman.2008.02.015.

8. Park, S.B., Jang, Y.I., Lee, J. \& Lee, B.J. (2009). An experimental study on the hazard assessment and mechanical properties of porous concrete utilizing coal bottom ash coarse aggregate in Korea. J.Hazard.Mater. 166 (1), 348-355. DOI:10.1016/j.jhazmat.2008.11.054.

9. Kurbatskij, M.N., Radionov, B.I., Kudryashov, S.Yu., Kryukov, M.Yu., Kul'pin, A.V. \& Samojlov, Yu.A. (2002). Manufacturing of mineral wool products on basis of slags. Metallurg 1, 49-51.

10. Mihok, L., Demeter, P., Baricova, D. \& Seilerova, K. (2006). Utilization of ironmaking and steel making slags. Metalurgija 45 (3), 163-168.

11. EUROPEAN COMMISSION, Radiological Protection Principles Concerning the Natural Radioactivity of Building 
Materials, Radiation Protection 112, European Commission, Directorate-General, Environment, Nuclear Safety and Civil Protection, 1999, p.11.

12. Londhe, V.S., Rao, S.R. \& Pillai, K.C. (1984). Assessment of natural radioactivity levels in building materials and evaluation of indoor radiation exposure. Environ. Technol. 5 (1), 81-88. DOI: 10.1080/09593338409384256.

13. Mustonen, R. (1984). Natural radioactivity in and radon exhalation from Finnish building materials. Health Phys. 46(6), 1195-1203.

14. Xinwei, L. (2006). Natural radioactivity in some building materials and by-products of Shaanxi, China. J. Radioanal. Nucl. Ch.262 (3), 775-777. DOI: 10.1007/s10967-004-0509-4.

15. Al-Saleh, F.S. \& Al-Berzan, B. (2007). Measurements of natural radioactivity in some kinds of marble and granite used in Riyadh region. J. Nucl.Radiat. Phys. 2 (1), 25-36.

16. Manea, C., Podina, C., Pordea, I., Crutu, G., Ilie, G. \& Robu, I. (2008). The estimation of cements radioactivity obtained by electrofilter ashes addition due to thermal power station based on coal from Oltenia Coalfield, Romania. Analele Universitatii din Bucuresti - Chimi. Anul XVII 1, 45-49.

17. Turhan, A., Baykan, U.N. \& Sen, K. (2008). Measurement of the natural radioactivity in building materials used in Ankara and assessment of external doses. J. Radiol. Prot. 28 (1), 83-87. DOI: 10.1088/0952-4746/28/1/005.

18. Manea, C., Podina, C., Pordea, I., Crutu, G., Ilie, G. \& Robu, I. (2010). The radiological risk assessment due to the radioactivity of thermal power station ashes added in building materials. Rev. Roum. Chim. 55 (1), 39-44.

19. Minh Hoang, T., Thi Hong, L., Van Doan, N. \& Thi Sao, K. (2008). Building standards on natural radioactivity in building materials and in homes in Vietnam, Proceedings of The 3rd ACF International Conference-ACF/VCA 2008, pp. 1277-1281, http://www.vncold.vn/Modules/CMS/Upload/10/ New\%20folder/vca/Proceeding/Session\%20E/E13.pdf.

20. Ordinance on the conditions, methods and terms as well, for systematically research and monitoring of types and activities of radioactive substances in air, soil, see, rivers, lakes, underground waters, solid and liquid rainfalls, drinking water, food and stuff of commonly usage and housing and business rooms as well, Official Gazette No. 60/2008 (in Croatian).

21. Kovler, K. Radiation of Building materials. from http:/ /tx.technion.ac.il/ cvrkost/Krina/sld001.htm.

22. Radiation and Nuclear Safety Authority (STUK)GUIDE ST 12.2 2005. The radioactivity of building materials and ash, Helsinki 2005, ISSN 0789-4554, from http:// www.finlex.fi/pdf/normit/23857-ST12-2e.pdf.

23. Beretka, J, \& Mathwew, P.J. (1985). Natural Radioactivity of Australian Building Materials, Industrial Waste and ByProducts, Health Phys. 48, 87-95.

24. Mondal, T., Sengupta, D. \& Mandal, A. (2006). Natural radioactivity of ash and coal in major thermal power plants of West Bengal, India, Current Science, 91 (10), 1387-1393, from http://www.ias.ac.in/currsci/nov252006/1387.pdf.

25. Viruthagiri, G., Gobi, R. \& Rajamannan, B. (2009). Measurement of Natural Radioactivity in Porcelan Stoneware Tiles. Rec. Res. Sci. Technol. 1 (1), 30-33. from http://recentscience.com/article/view/895.

26. Krstić, D., Nikezić, D., Stevanović, N. \& Vučić, D. (2007). Radioactivity of some domestic and imported building materials from South Eastern Europe. Rad. Meas. 42, 1731-1736. DOI: $\quad 10.1016 /$ j.radmeas.2007.09.001. 